\title{
TREN PERTUMBUHAN LEMBAGA PENDIDIKAN PESANTREN DI BIMA TAHUN 2001-2012
}

\author{
Mukhlis \\ (Institut Agama Islam Negeri Mataram \\ email: mukhlisabali@yahoo.co.id)
}

Abstract: Studies on pesantren growth and development remains urgent. This paper aims to reveal the trend of pesantren growth in Bima (both District of Bima and Municipality of Bima), during 2001 to 2012 which was divided into three four-years, ie 2001-2004, 2005-2008, and 2009- 2012. Utilizing and analyzing data from the Ministry of Religious Affairs of Bima, the authors found that: (1) In the first four-years, 11 new pesantren emerged (growth average 2.75 per year) with a relatively consistent trend. (2) In the second four-years, 21 new pesantren born (average 5.25 per year) with very volatile trend. (3) In the third four-years, 11 new pesantren born (average 2.75 per year) with a fairly volatile trend. (4) Overall, during 2001 to 2012, 43 pesantren born (average 3.58 per year) with a fluctuative growth rate. Pesantren growth reached its peak in 2008 when 10 (23.26\%) new pesantren born.

Abstrak: Kajian tentang pertumbuban dan perkembangan pesantren tetap urgen dilakukan. Tulisan ini bertujuan untuk mengungkapkan tren pertumbuhan pesantren di Bima (Kabupaten Bima dan Kota Bima) selama tabun 2001 sampai 2012 yang dibagi menjadi tiga catur tabun, yaitu 2001-2004, 2005-2008, dan 2009-2012. Dengan memanfaatkan dan menganalisis data-data dari Kementerian Agama Kabupaten Bima dan Kota Bima, penulis menemukan bahwa: (1) Pada catur tabun pertama, 11 pesantren baru labir (rerata 2,75 per tahun) dengan tingkat yang relatif konsisten. (2) Pada catur kedua, 21 pesantren baru muncul (rata-rata 5,25 per tabun) dengan tingkat yang sangat fluktuatif. (3) Pada catur tabun ketiga, 11 pesantren baru tumbuh (rata-rata 2,75 per tabun) dengan tingkat yang cukup fluktuatif. (4) Secara keseluruban, selama tabun 2001-2012 terdapat 43 pesantren baru yang muncul (agregat pertumbuhan 3,58 per tahun) dengan tingkat pertumbuhan yang fluktuatif. Tabun 2008 merupakan puncak pertumbuban pesantren di Bima dengan munculnya 10 (23,26\%) pesantren baru.

Keywords: pesantren, pertumbuhan, tren, Kabupaten Bima, Kota Bima. 
HASIL-hasil kajian tentang pondok pesantren (selanjutnya disebut pesantren saja), bila dicermati, hampir selalu mengambil objek dan setting Jawa, Madura atau Sumatera. Meskipun hal itu dapat dimengerti karena di tiga pulau itulah pesantren mengalami masa-masa awal pembentukannya sejak abad ke-18, hal itu juga disayangkan karena geliat dan dinamika pesantren di luar tiga pulau itu menjadi agak luput dari kajian-kajian ilmiah. Hal itu sekaligus memberikan peluang bagi penelitian yang serius tentang dinamika pesantren di luar tiga pulau tersebut, misalnya di Bima, Nusa Tenggara Barat.

Dalam tulisan ini nama Bima digunakan untuk merujuk kepada dua wilayah sekaligus, Kabupaten Bima (selanjutnya disingkat: Kabi) dan Kota Bima (selanjutnya disingkat Kobi), kecuali apabila disebutkan secara terpisah. Selain itu, ketika nama Bima ditulis dalam frasa "etnis Bima", maka itu merujuk kepada nama etnis yang merupakan penduduk asli dan menjadi penduduk mayoritas di Bima hingga saat ini. Selain etnis asli itu, di Bima juga terdapat penduduk dari beberapa etnis pendatang, seperti etnis Bugis, Samawa, Sasak, Flores, Bali, Jawa, Madura, Arab, dan Cina. Karakterisitik keberagamaan penduduk Bima adalah mayoritas muslim. Menurut data Badan Pusat Statistik (BPS) NTB tahun 2005, dari 508.302 pemeluk agama di daerah itu hampir seluruhnya, yaitu 503.405 (99.04\%) adalah muslim, sedangkan $4.897(0.96 \%)$ sisanya terdiri dari pemeluk agama Hindu 1.864 (0.37\%), Katolik 1.591 (0.31\%), Kristen 969 (0.19\%), dan Budha 473 (0.09\%). ${ }^{2}$ Dominannya jumlah muslim itu diikuti dengan banyaknya jumlah tempat ibadah Islam (masjid, langgar, dan mushalla) untuk mendukung pelaksanaan ibadah dan kegiatan keislaman lainnya, serta aneka institusi/lembaga penyelenggara pendidikan Islam, ${ }^{3}$ seperti

${ }^{1}$ Hanun Asrohah. Pelembagaan Pesantren Asal Usul dan Perkembangan Pesantren di Jawa. Jakarta: Bagian Proyek Peningkatan Informasi Penelitian dan Diklat Keagamaan Depag. RI, 2004. Buku ini adalah publikasi dari disertasi penulisnya di IAIN Syarif Hidayatullah, Jakarta, 2002.

${ }^{2}$ Badan Pusat Statistik Provinsi NTB, Nusa Tenggara Barat dalam Angka 2006/2007, 156.

3Jika ditilik dari aspek program dan praktik penyelenggaraannya, pendidikan Islam setidaknya dapat dikelompokkan ke dalam enam jenis, yaitu: (1) Pondok pesantren atau madrasah diniyah; (2) Madrasah dan 
madrasah, pesantren, perguruan tinggi Islam, dan sentra-sentra pendidikan al-Qur'an baik di masjid dan mushalla maupun di rumah-rumah penduduk.

Fenomena pesantren di Bima, Nusa Tenggara Barat (NTB), dapat dikatakan sebagai fenomena baru. Sistem pendidikan pesantren di Bima baru berusia 40-an tahun, dihitung dari tahun berdirinya pesantren tertua di daerah itu, Pesantren Darul Furqan, tahun $1968 .{ }^{4}$ Kenyataan itu agak mencengangkan bila dihubungkan dengan usia masuk dan berkembangnya Islam di daerah tersebut yang sudah mencapai sekitar 400-an tahun. Islam masuk ke tanah Bima pada tahun 1609; dan masyarakat Bima secara masif telah menganut Islam sejak paroh pertama abad XVII. ${ }^{5}$ Dibandingkan dengan banyak daerah lain yang juga

pendidikan lanjutannya yang bernaung di bawah Departemen Agama; (3) Pendidikan umum yang bernapaskan Islam yang bernaung di bawah yayasan dan organisasi Islam; (4) Pelajaran agama Islam sebagai suatu mata pelajaran atau mata kuliah, dan/atau program studi; (5) Pendidikan Islam dalam keluarga atau tempat-tempat ibadah dan/atau forum-forum kajian keislaman, majelis ta lim, dan institusi-institusi lainnya yang diselenggarakan oleh masyarakat; (6) Pendidikan di sekolah atau di luar sekolah yang disemangati oleh ajaran dan nilai-nilai Islam yang dikembangkan oleh pendidik atau tenaga kependidikan muslim yang memiliki komitmen, loyalitas, dan dedikasi tinggi terhadap Islam. Lihat Muhaimin, Nuansa Baru Pendidikan Islam Mengurai Benang Kusut Dunia Pendidikan Jakarta: Raja Grafindo Persada, 2006), 20-1.

4Kementerian Agama Kabupaten Bima, Data Pesantren Tabun 2013 (Bima: Kementerian Agama Kabupaten Bima, 2013).

5Terdapat kontroversi di kalangan sejarawan tentang waktu dan asal kedatangan Islam ke Bima. Setidaknya terdapat enam pendapat yang berbeda di kalangan sejarawan yang mengkaji masalah itu dengan menyebutkan angka tahun yang berbeda-beda, yaitu: $1050 \mathrm{H}$ atau $1640 \mathrm{M}$ menurut Ahmad Amin, lihat Ahmad Amin, Sejarab Bima (Bima: Depdikbud, 1971), 9; $1028 \mathrm{H}$ atau $1608 \mathrm{M}$ menurut M. Fachrir Rahman, lihat M. Fachrir Rahman, "Kontroversi Sejarah Masuk Islam ke Bima", Ulumuna, vol IX, no. 1 (Januari-Juni 2005), 20-34; 26 April 1619 M menurut Syukri H. Ibrahim, lihat Syukri H. Ibrahim, Sultan Abdul Khair Sirajuddin dan Peranannya dalam Pengembangan Islam di Kesultanan Bima, Skripsi (Surabaya: Fakultas Adab IAIN Sunan Ampel, 1989); 1617 menurut Abdullah Tajib, lihat Abdullah Tayeb, Sejarah Bima Dana Mbojo (Jakarta: Harapan Masa PGRI, 1995), 110-7; 1609 menurut Abdullah Ahmad, lihat Abdullah Ahmad, Kerajaan Bima dan Keberadaannya (Bima: t.p. 1992), h. 23 dan 52-5. Bahkan Zollinger menyebutkan angka yang jauh lebih tua lagi, yaitu 1450 atau 1540, 
telah berabad-abad menerima Islam dan mayoritas penduduknya muslim — seperti Jawa, Madura, Sumatera, dan Lombok- Bima dapat dibilang sangat terlambat mengadopsi sistem pendidikan ala pesantren. Faktor apa yang membuat Bima terlambat dalam mengadopsi sistem pendidikan pesantren merupakan pertanyaan yang menarik untuk ditelusuri jawabannya.

Hingga tahun 1990 atau 22 tahun setelah berdirinya Pesantren Darul Furqan pada tahun 1968, jumlah pesantren di Bima hanya mencapai sepuluh buah, atau hanya bertambah delapan buah pesantren baru. Tetapi, jika menilik masa 22 tahun berikutnya (1991-2012) jumlah pesantren mengalami peningkatan yang signifikan hingga mencapai 63 buah. ${ }^{6}$ Artinya, dalam masa 22 tahun kedua itu pesantren telah bertambah jumlahnya sebanyak 53 buah atau naik lebih dari $500 \%$ dari jumlah semula, 10 sebuah. Hal itu menunjukkan adanya derap pertumbuhan yang cukup pesat dalam masa 44 tahun sejarah perpesantrenan di Bima. Pertumbuhan pesantren, tentu saja, setiap tahunnya tidak selalu lempang dan sama jumlahnya. Tahun-tahun terntentu menujukkan pertumbuhan yang lebih tinggi dibandingkan dengan tahun yang lainnya atau lebih rendah, atau bahkan nihil pertumbuhan. Kenyataan itu bermakna bahwa fenomena pertumbuhan pesantren itu menunjukkan dirinya sebagai fenomena yang cukup fluktuatif. Kenyataan itu mengindikasikan adanya fenomena dinamika pesantren di Bima. Tulisan ini mengkhususkan diri masa 12 tahun dalam rentang tahun 2000-2012. Diasumsikan bahwa dinamika pesantren di Bima pada dasawarsa pertama milenium ketiga ini akan menjadi pondasi bagi perkembangan pesantren di daerah itu pada masa-masa yang akan datang. Untuk kepentingan analisis, masa 12 tahun itu dibagi menjadi tiga catur tahun, yaitu 2001-2004, 2005-2008, dan 2009-2012.

sebagaimana dikutip oleh Abdullah Tayeb, Sejarah Bima Dana Mbojo (Jakarta: Harapan Masa PGRI, 1995), 106-7.

'Kementerian Agama Kabupaten Bima, Data Pesantren Tabun 2013 (Bima: Kementerian Agama Kabupaten Bima, 2013); dan Kementerian Agama Kota Bima, Data Pesantren Tabun 2013 (Bima: Kementerian Agama Kota Bima, 2013). 


\section{Konseptualisasi Perkembangan Pesantren}

Kajian tentang perkembangan suatu institusi baik sosial maupun pendidikan, semisal perkembangan pondok pesantren, dapat dipapar dengan model penulisan sejarah diakronik atau sinkronik. Pola diakronik menyajikan paparan historis tentang suatu peristiwa dengan mengikuti urutan kejadiannya dalam rentang waktu dari awal hingga batas waktu tertentu-biasanya cukup panjang meliputi waktu puluhan hingga ratusan tahundan mengesampingkan konteks yang lebih luas. Sebaliknya, pola sinkronik memaparkan peristiwa atau keadaaan dalam lingkup waktu yang terbatas, tetapi diurai dalam konteks yang lebih luas dan mendalam serta menelusuri keterkaitannya dengan peristiwa-peristiwa lain yang semasa. ${ }^{7}$ Pola yang pertama merupakan pola utama kajian kesejarahan dalam tulisan ini, meskipun dalam masalah-masalah tertentu peneliti menyajikan pola papar yang diakronik.

Suatu sistem institusi pendidikan memiliki berbagai unsur yang terlibat di dalamnya yang meliputi unsur organik dan anorganik. Dihubungkan dengan sistem pendidikan pesantren maka unsur organiknya adalah kyai, ustadz, santri, dan pengurus pondok pesantren; sedangkan unsur anorganiknya meliputi masjid atau surau sebagai pusat kegiatan peribadatan, sekolah atau ruang-ruang belajar sebagai pusat kegiatan belajar-mengajar, rumah kyai dan ustaz, pondok tempat tinggal para santri, dan sejumlah perangkat lunak, seperti tujuan, kurikulum, kitab atau sumber belajar, metode pengajaran, perpustakaan, pusat dokumentasi, penerangan, keterampilan, dan pusat pengembangan masyarakat. ${ }^{8}$

Pertumbuhan pesantren merupakan suatu proses dinamis, suatu dinamika. Dalam ilmu sosial istilah itu digunakan dalam beragam konteks. Pertama, merujuk kepada 'dinamika suatu fenomena', dengan fokus pada bagaimana fenomena itu berubah

${ }^{7}$ Kuntowijoyo. Metodologi Sejarah. Edisi ke-2 (Yogyakarta: Tiara Wacana, 2003), 43-46; Kuntowijoyo, Pengantar Ilmu Sejarah (Yogyakarta: Bentang, 2005), 108-125; Peter Burke, Sejarah dan Teori Sosial. terj. oleh Mestika Zed dan Zulfami, Edisi ke-3 (Jakarta: Yayasan Obor Indonesia, 2003).

${ }^{8}$ Mastuhu, Dinamika Sistem Pendidikan Pesantren: Suatu Kajian tentang Unsur dan Nilai Sistem Pendidikan Pesantren (Jakarta: INIS, 1994), 19 dan 25. 
sepanjang waktu; penekanan utamanya pada fenomena sosial yang substantif, dan progres penelitian bergantung pada pemahaman teoritis yang mendalam dan pengetahuan empiris yang luas tentang fenomena tersebut. Kedua, merujuk kepada 'model dinamis dari suatu fenomena', tujuannya adalah untuk memformulasikan, menguji, dan menelusuri konsekuensikonsekuensi dari seperangkat asumsi matematis atau algoritma komputer yang dimaksudkan untuk meniru prilaku fenomena. Ketiga, merujuk kepada 'analisis dinamis terhadap data empiris tentang suatu fenomena', mencakup bentuk-bentuk analisis temporal (longitudinal) data yang menyangkut titik-titik waktu yang berbeda. ${ }^{9}$

Perubahan suatu sistem sosial tertentu dapat bersifat endogenous dan exogenous. Perubahan endogenous adalah perubahan dalam sebuah sistem yang ditimbulkan oleh kekuatan-kekuatan yang interdependen dan efek-efek umpan-balik dalam sistem itu sendiri; sedangkan perubahan exogenous adalah perubahan dalam suatu sistem yang dipengaruhi oleh sebab-sebab yang berasal dari luar sistem itu. Prinsip interdependensi dan umpan balik dalam suatu sistem memunculkan perubahan endogenous, karena adanya tindakan (action) salah satu elemen sistem akan menimbulkan tindakan balasan (counteraction) dari elemen yang lain; demikian pula perubahan pada suatu variabel akan memunculkan perubahan yang berlawanan atau memperkuat dari variabel lainnya. ${ }^{10}$

Dari pespektif dinamika endogenous pesantren dipandang sebagai satu sistem tersendiri yang dilengkapi dengan unsurunsur yang membentuknya. Unsur utama dan menjadi karakteristik penting pesantren, menurut Zamakhsyari Dhofier, adalah pondok, masjid, pengajaran kitab klasik, santri, dan kyai. ${ }^{11}$ Menurut Mastuhu, ${ }^{12}$ unsur-unsur dalam pesantren itu dapat

9Nancy Brandon Tuma, "Social Dynamics", dalam Encyclopedia of Sociology, Second Edition, Vol. 4, eds. Edgar F. Borgatta and Rhonda J. V. Montgomery (New York: Macmillan Reference USA, 2000), 2663.

${ }^{10}$ Ibid., 2664.

${ }^{11}$ Untuk detail tentang lima unsur itu, lihat Zamakhsyari Dhofier, Tradisi Pesantren: Studi tentang Pandangan Hidup Kyai (Jakarta: LP3ES, 1994).

${ }^{12}$ Mastuhu, Dinamika...., 19 dan 25. 
dibedakan menjadi unsur organik (meliputi kyai, ustadz, santri, dan pengurus pondok pesantren) dan anorganik (meliputi masjid atau surau sebagai pusat kegiatan peribadatan, sekolah atau ruang-ruang belajar sebagai pusat kegiatan belajar-mengajar, rumah kyai dan ustaz, pondok tempat tinggal para santri, dan sejumlah perangkat lunak, seperti tujuan, kurikulum, kitab atau sumber belajar, metode pengajaran, perpustakaan, pusat dokumentasi, penerangan, keterampilan, dan pusat pengembangan masyarakat.

Dari perspektif dinamika exogenous, pesantren dipandang sebagai salah satu subsistem di dalam susbsistem yang lebih besar, misalnya sistem pendidikan Islam atau yang lebih besar lagi adalah sistem pendidikan nasional. Dalam konteks ini pesantren berada dalam interaksi dengan sistem-sistem lain di sekitarnya. Oleh karena itu, pada suatu saat dan dalam sisi tertentu, dinamika pesantren dipengaruhi oleh dinamika sistem lain, dan pada saat dan dalam sisi yang lain, pesantren memberikan pengaruhnya terhadap sistem yang lain.

\section{Awal Kemunculan Pesantren di Bima}

Penelusuran terhadap berbagai referensi dan dokumen tentang sejarah pesantren di Bima memberikan informasi bahwa pesantren di daerah itu munculnya jauh lebih kemudian dibandingkan dengan di daerah Lombok yang sama-sama merupakan daerah dalam wilayah provinsi NTB. Sistem pendidikan pesantren di Bima baru berusia 40-an tahun. Pesantren tertua yang diketahui adalah Pesantren Darul Furqan yang didirikan tahun $1968 .{ }^{13}$ Kenyataan itu agak mencengangkan bila dihubungkan dengan usia masuk dan berkembangnya Islam di daerah tersebut yang sudah mencapai sekitar 400-an tahun. Islam masuk ke tanah Bima pada tahun 1609; dan masyarakat Bima secara masif telah menganut Islam sejak paroh pertama abad XVII. Dibandingkan dengan banyak daerah lain yang juga telah berabad-abad menerima Islam dan mayoritas penduduknya muslim — seperti Jawa, Madura, Sumatera, dan Lombok— Bima

${ }^{13}$ Kementerian Agama Kota Bima, Data Pesantren Tabun 2013 (Bima: Kementerian Agama Kota Bima, 2013). 
dapat dibilang sangat terlambat mengadopsi sistem pendidikan ala pesantren.

Pesantren Darul Furqan didirikan di desa Dodu oleh seorang guru bernama H. Abdul Karim, seorang guru Pegawai Negeri Sipil (PNS) dan qari yang cukup terkenal di Bima. Kegiatan selaku seni membaca al-Qur'an membawanya terlibat dalam berbagai MTQ (Musabaqah Tilawatil Qur'an) baik sebagai peserta lomba, panitia, maupun juri (Dewan Hakam) mulai tingkat desa/kelurahan hingga nasional. Kegiatan itu pula yang membuatnya memiliki pergaulan yang luas dengan kalangan ulama baik lokal maupun nasional sehingga dia memiliki kesempatan yang cukup luas untuk menimba pengetahuan dan pengalaman. Di antara pengetahuan dan pengalaman itu adalah yang berkaitan dengan lembaga pendidikan pesantren yang ditimbanya dari beberapa kyai asal Jawa yang dikenalnya dan menjadi sejawatnya dalam kegiatan seni membaca al-Qur'an. Dia terinspirasi dengan perjuangan para kyai itu dalam membangun psantren. Dia pun terobsesi untuk membangun lembaga pendidikan yang sama di Bima, yaitu di desa Dodu, tempat tinggalnya.

Pesantren Darul Furqan kini telah berusia 45 tahun. Berbagai perubahan dan perkembangan dialaminya hingga kini. Pesantren itu berkembang dari rintisan awal Karim yang sederhana hingga menjadi lembaga pendidikan Islam yang mapan baik secara kelembagaan maupun proses belajar mengajar di dalamnya. Pondok pesantren Darul Furqan telah memainkan peran sebagai pioneer bagi kemunculan pesantren di Bima. Setelah kemunculannya, beberapa tokoh masyarakat di Bima pun juga terinspirasi untuk mendirikan pesantren. Hal itu berlanjut dari tahun ke tahun. Data terkini tentang pesantren di Bima menunjukkan bahwa lembaga pendidikan itu telah mencapai jumlah 63 buah yang tersebar di wilayah Kobi dan Kabi. ${ }^{14}$ Di bawah ini akan dipaparkan perkembangan pesantren itu dalam rentang waktu 12 tahun awal abad XXI, yaitu dari

${ }^{14}$ Kementerian Agama Kota Bima, Data Pesantren Tahun 2013 (Bima: Kementerian Agama Kota Bima, 2013); Kementerian Agama Kabupaten Bima, Data Pesantren Tabun 2013 (Bima: Kementerian Agama Kabupaten Bima, 2013). 
tahun 2001 sampai dengan 2012. Rentang waktu tersebut dibagi menjadi tiga periodesasi catur tahun, yaitu masing-masing empat tahun. Pada setiap periodesasi diuraikan tren pertumbuhan pesantren di Bima.

\section{Pertumbuhan Pesantren tahun 2001-2004}

Dalam rentang waktu antara tahun 2001 sampai dengan 2004 lahir sebelas buah pesantren. Tabel 1 di bawah ini menyajikan informasi tentang nama, tahun berdiri, nama tokoh pendiri, dan lokasi kemunculan pesantren-pesantren dalam rentang waktu tersebut. Informasi yang dapat ditangkap dari paparan data dalam Tabel 1 itu adalah bahwa angka pertumbuhan pesantren dalam rentang masa 2001-2004 relatif konsisten di mana pada setiap tahunnya tumbuh tiga buah pesantren, kecuali pada tahun 2003 hanya dua pesantren. Konsistensi tersebut mengindikasikan adanya dinamika positif dalam geliat pertumbuhan pesantren di Bima. Rata-rata pertumbuhan pesantren dalam masa ini adalah 2,75 buah per tahun. Dari segi lokasi kemunculannya, tiga pesantren $(27,27 \%)$ lahir di wilayah administratif Kobi sedangkan delapan pesantren $(72,73 \%)$ muncul di Kabi.

Sementara itu, Tabel 2 menunjukkan bagaimana tren pertumbuhan pesantren di Bima dalam rentang waktu 20012004 berlangsung. Dalam rentang waktu tersebut, di wilayah Kabi terjadi satu tahun nihil-pertumbuhan pesantren, yaitu tahun 2003, sedangkan di Kobi terjadi dua tahun-nihil, yaitu 2001 dan 2004. Jadi, dalam rentang tahun 2001 sampai dengan 2004 terdapat tiga tahun nihil pertumbuhan pesantren baru, yaitu pada tahun 2001, 2003, dan 2004 .

\section{Tabel 1}

Pertumbuhan Pesantren di Bima Tahun 2001-2004

\begin{tabular}{|c|l|c|l|c|}
\hline No. & \multicolumn{1}{|c|}{ Nama Pesantren } & $\begin{array}{c}\text { Tahun } \\
\text { Berdiri }\end{array}$ & \multicolumn{1}{|c|}{ Pendiri } & Lokasi \\
\hline 1 & Al- Ikhlas Nunggi & 2001 & Hj. Siti Safiah & Kabi \\
\hline 2 & Al- Madinah & 2001 & Jabir & Kabi \\
\hline 3 & Al- Falah Rade & 2001 & Muhaimin & Kabi \\
\hline 4 & Al- Ikhwan & 2002 & H. Zainul Arifin & Kabi \\
\hline
\end{tabular}




\begin{tabular}{|c|l|c|l|c|}
\hline No. & \multicolumn{1}{|c|}{ Nama Pesantren } & $\begin{array}{c}\text { Tahun } \\
\text { Berdiri }\end{array}$ & \multicolumn{1}{|c|}{ Pendiri } & Lokasi \\
\hline 5 & Al- Fakhir & 2002 & H. A. Karim & Kabi \\
\hline 6 & Nurul Mukhtar & 2002 & Muhtar Yasin & Kabi \\
\hline 7 & Khalid Bin Walid & 2003 & H. Ajrun Sulaiman & Kabi \\
\hline 8 & Darul Ulumi Wal Amal & 2003 & H. Affandi H. Ibrahim & Kabi \\
\hline 9 & Miftahul Khair & 2004 & Kadru & Kabi \\
\hline 10 & Darun Nurhayati & 2004 & Sarujin Nurdin & Kabi \\
\hline 11 & Ibnu Sina & 2004 & Sudirman Ibnu & Kabi \\
\hline
\end{tabular}

Sumber: Data Pondok Pesantren dari Kemenag Kabi dan Kobi tahun 2013.

\section{Tabel 2}

Tren Pertumbuhan Pesantren di Bima Tahun 2001-2004

\begin{tabular}{|c|l|c|c|c|c|c|c|c|c|c|c|}
\hline \multirow{2}{*}{ No. } & \multirow{8}{*}{ Lokasi } & \multicolumn{7}{|c|}{ Tahun Berdiri } & Jumlah \\
\cline { 2 - 13 } & $\mathbf{2 0 0 1}$ & $\mathbf{0}$ & $\mathbf{2 0 0 2}$ & $\mathbf{\%}$ & $\mathbf{2 0 0 3}$ & $\mathbf{\%}$ & $\mathbf{2 0 0 4}$ & $\mathbf{\%}$ & $\mathbf{n}$ & $\mathbf{\%}$ \\
\hline 1 & Kabi & 3 & 27.27 & 2 & 18,18 & 0 & 0 & 3 & 27,27 & 8 & 72,73 \\
\hline 2 & Kobi & 0 & 0 & 1 & 9,09 & 2 & 18,18 & 0 & 0 & 3 & 27,27 \\
\hline \multicolumn{2}{|c|}{ Jumlah } & 3 & 27.27 & 3 & 14,29 & 1 & 4,76 & 10 & 47,62 & 11 & 100 \\
\hline
\end{tabular}

\section{Pertumbuhan Pesantren tahun 2005-2008}

Dalam rentang waktu antara tahun 2001 sampai dengan 2004 lahir 21 buah pesantren. Tabel 3 di bawah ini menyajikan informasi tentang nama, tahun berdiri, nama tokoh pendiri, dan lokasi kemunculan pesantren-pesantren dalam rentang waktu tersebut.

Tabel 3

Pertumbuhan Pesantren di Bima Tahun 2005-2008

\begin{tabular}{|c|l|c|l|c|}
\hline No. & \multicolumn{1}{|c|}{ Nama Pesantren } & $\begin{array}{c}\text { Tahun } \\
\text { Berdiri }\end{array}$ & \multicolumn{1}{|c|}{ Pendiri } & Lokasi \\
\hline 1 & As- Samiun & 2005 & A. Bakar Usman & Kabi \\
\hline 2 & Al- Mutmainah & 2005 & Fahris Adam & Kabi \\
\hline 3 & Al- Anshar & 2005 & Syarifudin & Kabi \\
\hline 4 & Ulil Albab & 2005 & Supardi & Kabi \\
\hline
\end{tabular}




\begin{tabular}{|c|l|c|l|c|}
\hline No. & \multicolumn{1}{|c|}{ Nama Pesantren } & $\begin{array}{c}\text { Tahun } \\
\text { Berdiri }\end{array}$ & \multicolumn{1}{|c|}{ Pendiri } & Lokasi \\
\hline 5 & Umar Bin Abdul Azis & 2005 & Effendi & Kabi \\
\hline 6 & Nurul Ahmady & 2005 & Mursalmal & Kabi \\
\hline 7 & Al- Aqhbar & 2005 & Lilis Mulyadi & Kabi \\
\hline 8 & Al- Anwary & 2006 & M. Ali Hasan & Kabi \\
\hline 9 & Al- Nur & 2006 & Abdul Hamid & Kabi \\
\hline 10 & Faridatunnisa & 2006 & Fifi Faridah & Kabi \\
\hline 11 & Ihya Ulumuddin & 2007 & Jumadil & Kabi \\
\hline 12 & Uswatul Husna & 2008 & Maatuh & Kabi \\
\hline 13 & Ulil Albab & 2008 & Yohana & Kabi \\
\hline 14 & Darul Hamid & 2008 & A. Hamid & Kabi \\
\hline 15 & Ar- Rahman & 2008 & M Yamin & Kabi \\
\hline 16 & Al Maliki & 2008 & A. Fitra Malik & Kabi \\
\hline 17 & As-Salam & 2008 & Sahlan & Kabi \\
\hline 18 & Raudhatul Ulum & 2008 & M. Sidik & Kabi \\
\hline 19 & Nurul Huda & 2008 & H. Mahmud & Kabi \\
\hline 20 & Ar Rahman Kuta & 2008 & Zukarnain & Kabi \\
\hline 21 & Al Waqi'ah & 2008 & As'an Hidayat & Kabi \\
\hline
\end{tabular}

Sumber: Data Pondok Pesantren dari Kemenag Kabi dan Kobi tahun 2013.

Data dalam Tabel 3 di atas menunjukkan bahwa dalam rentang waktu 2005 hingga 2008 muncul 21 pesantren di Bima. Tingkat pertumbuhan pesantren dalam rentang masa tersebut sangat fluktuatif di mana pada satu tahun tertentu lahir banyak pesantren, sedangkan pada tahun yang lainnya hanya sedikit sekali pesantren yang lahir. Rata-rata pertumbuhan pesantren dalam masa ini adalah 5,25 buah per tahun. Tahun 2008 tercatat sebagai puncak pertumbuhan pesantren dalam rentang tahun 2005 sampai 2008 di mana muncul sepuluh pesantren (47,62\%); sedangkan tahun 2007 hanya muncul satu pesantren (4,76\%). Bila dihubungkan dengan jumlah keseluruhan pesantren yang muncul dalam rentang waktu 2001-2012, maka angka pertumbuhan pesantren dalam tahun 2005-2008 itu adalah 23,25 $\%$, sebuah pencapaian tingkat pertumbuhan yang cukup tinggi. 
Tabel 4

Pertumbuhan Pesantren di Bima Tahun 2005-2008

\begin{tabular}{|c|c|c|c|c|c|c|c|c|c|c|c|}
\hline \multirow{2}{*}{ No. } & \multirow{2}{*}{ Lokasi } & \multicolumn{8}{|c|}{ TahunBerdiri } & \multicolumn{2}{|c|}{ Jumlah } \\
\hline & & 2005 & $\%$ & 2006 & $\%$ & 2007 & $\%$ & 2008 & $\%$ & $\mathbf{N}$ & $\%$ \\
\hline 1 & Kabi & 7 & 33.33 & 3 & 14,29 & 1 & 4,76 & 10 & 47,62 & 21 & 100 \\
\hline 2 & Kobi & 0 & 0 & 0 & 0 & 0 & 0 & 0 & 0 & 0 & 0 \\
\hline \multicolumn{2}{|c|}{ Jumlah } & 7 & 33.33 & 3 & 14,29 & 1 & 4,76 & 10 & 47,62 & 21 & 100 \\
\hline
\end{tabular}

Tabel 4 di atas ini menunjukkan tren pertumbuhan pesantren yang sangat fluktuatif dalam interval tahun 2005 sampai 2008. Selain pertumbuhan yang sangat fluktuatif, dalam rentang waktu tersebut pertumbuhan pesantren pun hanya terjadi dalam wilayah Kabi. Jadi, selama empat tahun itu tidak ada satu pun (nihil) pesantren baru yang muncul di wilayah Kobi.

\section{Pertumbuhan Pesantren tahun 2009-2012}

Dalam rentang waktu antara tahun 2009 sampai dengan 2012 lahir 21 buah pesantren di Bima. Tabel 5 di bawah ini menyajikan informasi tentang nama, tahun berdiri, nama tokoh pendiri, dan lokasi kemunculan pesantren-pesantren dalam rentang waktu tersebut.

Tabel 5

Pertumbuhan Pesantren di Bima Tahun 2009-2012

\begin{tabular}{|c|l|c|l|c|}
\hline No. & \multicolumn{1}{|c|}{ Nama Pesantren } & $\begin{array}{c}\text { Tahun } \\
\text { Berdiri }\end{array}$ & \multicolumn{1}{|c|}{ Pendiri } & Lokasi \\
\hline 1 & Daarul Muttaqien & 2009 & M. Sidik & Kobi \\
\hline 2 & Hamzanwadi NW & 2010 & H. Hasanuddin & Kobi \\
\hline 3 & Tahfiz "Nurul Jihad" & 2010 & Ilyas & Kobi \\
\hline 4 & Ar Rasyidin & 2010 & H.Rasyid & Kabi \\
\hline 5 & Al Islamuljannah & 2010 & Salahuddin & Kabi \\
\hline 6 & Al-Jihad & 2010 & Abbas Abdullah & Kabi \\
\hline 7 & Ahlu Nazar & 2010 & Syarifuddin & Kabi \\
\hline 8 & Qurratan A'yun & 2010 & Adi Wibowo & Kabi \\
\hline 9 & As - Shiddiqiyah & 2011 & Abubakar H. M. Sidik & Kabi \\
\hline
\end{tabular}




\begin{tabular}{|c|l|c|l|c|}
\hline No. & \multicolumn{1}{|c|}{ Nama Pesantren } & $\begin{array}{c}\text { Tahun } \\
\text { Berdiri }\end{array}$ & \multicolumn{1}{|c|}{ Pendiri } & Lokasi \\
\hline 10 & As - Syukur & 2011 & Anwar Sanusi & Kabi \\
\hline 11 & Ulul Albaab & 2012 & Islahuddin & Kobi \\
\hline
\end{tabular}

Sumber: Data Pondok Pesantren dari Kemenag Kabi dan Kobi tahun 2013.

Data dalam Tabel 5 di atas menunjukkan bahwa dalam rentang waktu 2009 hingga 2012 muncul 11 pesantren di Bima. Rata-rata pertumbuhan pesantren dalam masa ini adalah 2,75 buah per tahun. Tingkat pertumbuhan pesantren dalam rentang masa tersebut tidak merata di mana pada satu tahun tertentu lahir banyak pesantren, sedangkan pada tahun yang lainnya hanya satu pesantren yang lahir. Tahun 2010 tercatat sebagai puncak pertumbuhan pesantren dalam rentang tahun 2009 sampai 2012 di mana muncul tujuh pesantren (63,64\%); sedangkan tahun 2009 dan 2012 masing-masing hanya muncul satu pesantren $(9,09 \%)$.

Tabel 6

Tren Pertumbuhan Pesantren di Bima Tahun 2009-2012

\begin{tabular}{|c|l|c|c|c|c|c|c|c|c|c|c|}
\hline \multirow{2}{*}{ No. } & \multirow{2}{*}{ Lokasi } & \multicolumn{7}{|c|}{ TahunBerdiri } & Jumlah \\
\cline { 3 - 14 } & $\mathbf{2 0 0 9}$ & $\mathbf{\%}$ & $\mathbf{2 0 1 0}$ & $\mathbf{\%}$ & $\mathbf{2 0 1 1}$ & $\mathbf{\%}$ & $\mathbf{2 0 1 2}$ & $\mathbf{\%}$ & $\mathbf{N}$ & $\%$ \\
\hline 1 & Kabi & 0 & 0 & 5 & 45,45 & 2 & 18,18 & 0 & 0 & 7 & 63,64 \\
\hline 2 & Kobi & 1 & 9,09 & 2 & 18,18 & 0 & 0 & 1 & 9,09 & 4 & 36,36 \\
\hline \multicolumn{2}{|c|}{ Jumlah } & 1 & 9,09 & 7 & 63,64 & 2 & 18,18 & 1 & 9,09 & 21 & 100 \\
\hline
\end{tabular}

Tabel 6 di atas ini menunjukkan tren pertumbuhan pesantren yang cukup fluktuatif dalam interval tahun 2009 sampai 2012. Dalam rentang waktu tersebut di wilayah Kabi terjadi nihil pertumbuhan pesantren dalam dua tahun, yaitu 2009 dan 2012, sedangkan di Kobi terjadi pada tahun 2011.

\section{Tren Umum Pertumbuhan Pesantren di Bima 2001-2012}

Dalam paparan tiga sub bab sebelum telah dikemukan datadata pertumbuhan pesantren di Bima dalam setiap interval waktuh empat tahunan. Dalam sub bab ini dikemukakan tren 
umum pertumbuhan esantren itu dalam cakupan waktu 12 tahun, 2001 sampai 2012. Tabel 7 di bawah ini merangkum kecenderungan pertumbuhan pesantren di Bima.

\section{Tabel 7}

Tren Pertumbuhan Pesantren di Bima Tahun 2001-2012

\begin{tabular}{|c|c|c|c|c|c|c|c|}
\hline \multirow{2}{*}{ No } & \multirow{2}{*}{$\begin{array}{c}\text { Tahun } \\
\text { Berdiri }\end{array}$} & \multicolumn{2}{|c|}{ Kabi } & \multicolumn{2}{|c|}{ Kobi } & \multicolumn{2}{c|}{ Jumlah } \\
\cline { 3 - 8 } & $\mathbf{N}$ & $\%$ & $\mathbf{n}$ & $\%$ & $\mathbf{n}$ & $\%$ \\
\hline 1 & 2001 & 3 & 8,33 & 0 & 0,00 & 3 & 6,98 \\
\hline 2 & 2002 & 2 & 5,56 & 1 & 14,29 & 3 & 6,98 \\
\hline 3 & 2003 & 0 & 0,00 & 2 & 28,57 & 2 & 4,65 \\
\hline 4 & 2004 & 3 & 8,33 & 0 & 0,00 & 3 & 6,98 \\
\hline 5 & 2005 & 7 & 19,44 & 0 & 0,00 & 7 & 16,28 \\
\hline 6 & 2006 & 3 & 8,33 & 0 & 0,00 & 3 & 6,98 \\
\hline 7 & 2007 & 1 & 2,78 & 0 & 0,00 & 1 & 2,33 \\
\hline 8 & 2008 & 10 & 27,78 & 0 & 0,00 & 10 & 23,26 \\
\hline 9 & 2009 & 0 & 0,00 & 1 & 14,29 & 1 & 2,33 \\
\hline 10 & 2010 & 5 & 13,89 & 2 & 28,57 & 7 & 16,28 \\
\hline 11 & 2011 & 2 & 5,56 & 0 & 0,00 & 2 & 4,65 \\
\hline 12 & 2012 & 0 & 0,00 & 1 & 14,29 & 1 & 2,33 \\
\hline & Jumlahyyyyyyyyyy & 36 & 100 & 7 & 100 & 43 & 100 \\
\hline
\end{tabular}

Sumber: Data Pondok Pesantren dari Kemenag Kabi dan Kobi tahun 2013.

Data dalam tabel 7 di atas memberikan gambaran tentang tren pertumbuhan pesantren di Bima dalam rentang waktu tahun 2001 sampai 2012, yaitu terdapat 43 pesantren baru yang muncul. Perbedaan yang sangat timpang antara jumlah pesantren di Kabi (36 buah atau 83,72\%) dan Kobi (7 buah atau 16,27 \%) dapat dimengerti, karena perbandingan luas wilayah dan jumlah penduduk yang tidak berimbang antara keduanya. Wilayah Kobi 
yang sekarang, sebelum tahun 2002 hanyalah wilayah salah satu kecamatan (kecamatan Rasanae) dalam wilayah administratif Kabi. ${ }^{15}$

Tabel 7 di atas juga menunjukkan bahwa selama waktu 12 tahun tersebut setiap tahunnya selalu terdapat pesantren baru yang muncul di daerah itu. Pada tahun tertentu jumlah pesantren yang baru lahir jauh lebih banyak dibandingkan dengan tahun yang lainnya. Hal itu menunjukkan adanya dinamika pertumbuhan itu sendiri. Secara agregat pertumbuhan pesantren baru di Bima dalam masa 12 tahun itu adalah 3,58 per tahun.

Tahun 2008 merupakan puncak pertumbuhan pesantren di Bima dengan munculnya sepuluh pesantren baru. Jumlah itu adalah 23,26 \% dari 43 pesantren yang lahir dalam rentang masa 12 tahun tersebut. Kuantitas terbanyak kedua dalam kemunculan pesantren baru terjadi pada tahun 2005 dan 2010 dengan kemunculan masing-masing tujuh pesantren baru. Lahirnya tiga pesantren baru dalam satu tahun merupakan tren dalam 12 tahun yang disorot dalam tulisan ini, karena hal itu terjadi dalam empat tahun, yaitu 2001, 2002, 2004, dan 2006. Tren itu disusul dengan lahirnya satu pesantren dalam satu tahun; hal itu terjadi tahun 2007, 2009, dan 2012. Kemunculan dua pesantren baru dalam satu tahun terjadi dalam tahun 2003 dan 2011. Mengapa peak pertumbuhan pesantren baru terjadi pada tahun 2008 merupakan pertanyaan yang penting untuk dijawab melalui penelitian lebih lanjut.

Hal lain yang menarik untuk dicermati dari informasi dalam Tabel 7 di atas adalah bahwa dalam masa 12 tahun yang dicakup dalam penellitian ini terdapat tujuh tahun yang di dalamnya terjadi nihil pertumbuhan pesantren baru di wilayah Kobi. Lima dari tujuh tahun nihil itu terjadi berurutan, yaitu dari tahun 2004 sampai dengan 2008; sedangkan dua tahun nihil lainnya adalah 2001 dan 2011. Di pihak lain, Kabi hanya mengalami tiga tahun nihil, yaitu tahun 2003, 2009, dan 2012. Lima tahun nihil yang berurutan di Kobi itu menarik untuk dicermati lebih jauh untuk

${ }^{15}$ Kota Bima dibentuk berdasarkan Undang-Undang Nomor 13 Tahun 2002 tentang Pembentukan Kota Bima di Provinsi Nusa Tenggara Barat yang disahkan pada tanggal 10 April 2002; Lembaran Negara RI Tahun 2002 Nomor 26. 
mengetahui faktor-faktor yang melatarbelakanginya. Apa yang terjadi dengan dunia perpesantrenan di Kobi dalam waktu lima tahun tersebut merupakan pertanyaan yang penting untuk diadres lebih lanjut.

Bertolak belakang dengan kenyataan lima tahun nihil yang terjadi di Kobi itu, realitas pertumbuhan pesantren baru di Kabi justru mencapai puncaknya dalam masa tersebut. Dari 36 pesantren yang lahir baru di Kabi dalam rentang waktu 2001 sampai dengan 2012, justru terdapat 24 pesantren di antaranya $(66,67 \%)$ yang tumbuh dalam masa yang sama dengan masa nihil pesantren baru di Kobi (2004-2008). Hanya tujuh pesantren $(33,33 \%)$ yang tumbuh dalam tujuh tahun lainnya. Ini berarti bahwa lima tahun nihil di Kobi justru, sebaliknya, merupakan lima tahun emas pertumbuhan pesantren baru di Kabi.

\section{Catatan Akhir}

Pertumbuhan dan perkembangan pesantren di Bima dalam rentang satu dasawarsa pertama milennium ketiga, sebagaimana tersaji dalam table-tabel di atas, menyajikan sebuah fenomena yang memiliki dinamika yang cukup fluktuatif. Dinamika itu mengindikasikan adanya sejumlah peluang sekaligus tantangan yang melingkupi perkembangan pesantren di Bima. Selain itu, dinamika itu juga mengisyaratkan adanya sejumlah potensi kekuatan dan kelemahan dalam diri pesantren-pesantren itu yang membarengi pertumbuhan dan perkembangannya. Di atas semua itu, dinamika itu dapat dimaknai sebagai cerminan pergulatan pesantren dalam konteks sosial dan kultur masyarakat Bima. Dikatakan sebagai pergulatan karena sejatinya model pendidikan ala pesantren tidak dikenal dalam tradisi pendidikan Islam di Bima sejak masa Kesultanan Bima. Model itu mulai diintrodusir tahun 1968, beberapa tahun setelah era kesultanan itu berakhir. Usia pertumbuhan pesantren yang baru menginjak masa setengah abad merupakan sebuah prolog dari perkembangan lembaga pendidikan itu untuk masa-masa selanjutnya hingga menemukan bentuknya mapan dan "khas". Upaya-upaya terarah dan sistematis dari stakeholders pesantren penting untuk dilakukan dalam rangka mendorong lembaga pendidikan yang konon disebut sebagai khas Indonesia ini 
tumbuh dan berkembang dengan baik di Dana Mbojo, bumi Bima. Jika tidak, maka cuplikan dinamika yang tersaji di atas, pada masa yang akan dating, sekonyong-konyong akan menjadi cerita masa lalu. Wa al-Lāh a lam bi al-sawāh.

\section{Daftar Pustaka}

Achmad, Abdullah. 1992. Kerajaan Bima dan Keberadaannya. Bima: t.p.

Amin, Ahmad. 1971. Sejarah Bima. Bima: Depdikbud.

Asrohah, Hanun. 2004. Pelembagaan Pesantren Asal Usul dan Perkembangan Pesantren di Jawa. Jakarta: Bagian Proyek Peningkatan Informasi Penelitian dan Diklat Keagamaan Depag. RI.

Badan Pusat Statistik Provinsi NTB, Nusa Tenggara Barat dalam Angka 2006/2007.

Burke, Peter. 2003. Sejarah dan Teori Sosial. ter. oleh Mestika Zed dan Zulfami, Edisi ke-3. Jakarta: Yayasan Obor Indonesia.

Daulay, Haidar Putra. 2007. Sejarab Pertumbuban dan Pembaruan Pendidikan Islam di Indonesia. Jakarta: Kencana.

Dhofier, Zamakhsyari. 1994. Tradisi Pesantren: Studi tentang Pandangan Hidup Kyai. Jakarta: LP3ES.

Direktorat Jenderal Kelembagaan Agama Islam Depag. 2003. Pondok Pesantren dan Madrasah Diniyah: Pertumbuban dan Perkembangannya. Jakarta Direktorat Jenderal Kelembagaan Agama Islam Departemen Agama.

Ibrahim, Syukri H. 1989. Sultan Abdul Khair Sirajuddin dan Peranannya dalam Pengembangan Islam di Kesultanan Bima, Skripsi. Surabaya: Fakultas Adab IAIN Sunan Ampel.

Ismail, M. Hilir. 2004. Peran Kesultanan Bima dalam Perjalanan Sejarah Nusantara. Mataram: Lengge.

Kementerian Agama Kabupaten Bima, Data Pesantren Tahun 2013. Bima: Kementerian Agama Kabupaten Bima, 2013.

Kementerian Agama Kota Bima, Data Pesantren Tahun 2013.

Bima: Kementerian Agama Kota Bima, 2013.

Kuntowijoyo. 2003. Metodologi Sejarah. Edisi ke-2. Yogyakarta: Tiara Wacana. 
Bentang.

. 2005. Pengantar Ilmu Sejarah. Yogyakarta:

Lukens-Bull, Ronald Alan. 2004. Jihad Ala Pesantren di Mata Antropolog Amerika. ter. Abdurrahman Mas'ud, et.al. Yogyakarta: Gama Media.

Mastuhu. 1994. Dinamika Sistem Pendidikan Pesantren: Suatu Kajian tentang Unsur dan Nilai Sistem Pendidikan Pesantren. Jakarta: INIS.

Muhaimin. 2006. Nuansa Baru Pendidikan Islam Mengurai Benang Kusut Dunia Pendidikan. Jakarta: Raja Grafindo Persada.

Nasir, M. Ridlwan. 2005. "Dinamika Sistem Pendidikan: Studi di Pondok-pondok Pesantren Kabupaten Jombang Jawa Timur". Disertasi, PPs IAIN Sunan Kalijaga, Yogyakarta, 1995. Edisi buku, Mencari Tipologi Format Pendidikan Ideal Pondok Pesantren di Tengah Arus Perubahan. Yogyakarta: Pustaka Pelajar.

Rahman, M. Fachrir. "Kontroversi Sejarah Masuk Islam ke Bima”, Ulumuna, vol IX, no. 1 (Januari-Juni 2005)

Steenbrink, Karel A. 1986. Pesantren, Madrasah, Sekolab: Pendidikan Islam dalam Kurun Moderen, ter. Karel A. Steenbrink dan Abdurrahman. Jakarta: LP3ES.

Tayeb, Abdullah. 1995. Sejarah Bima Dana Mbojo. Jakarta: Harapan Masa PGRI.

Tuma, Nancy Brandon. "Social Dynamics", dalam Encyclopedia of Sociology, Second Edition, Vol. 4, eds. Edgar F. Borgatta and Rhonda J. V. Montgomery. New York: Macmillan Reference USA, 2000.

Undang-Undang Nomor 13 Tahun 2002 tentang Pembentukan Kota Bima di Provinsi Nusa Tenggara Barat yang disahkan pada tanggal 10 April 2002; Lembaran Negara RI Tahun 2002 Nomor 26. 